Article

\title{
Key Challenges and Opportunities for an Effective Supply Chain System in the Catalyst Recycling Market-A Case Study of Poland
}

\author{
Natalia Generowicz ${ }^{1, * \mathbb{C}}$, Joanna Kulczycka ${ }^{2}$, Monika Partyka ${ }^{3}$ and Kamil Saługa ${ }^{3}$ \\ 1 Mineral and Energy Economy Research Institute Polish Academy of Sciences, Wybickiego 7A Str., \\ 31-261 Cracow, Poland \\ 2 Faculty of Management, AGH University of Science and Technology, Mickiewicza 30, 30-059 Cracow, Poland; \\ kulczycka@agh.edu.pl \\ 3 Unimetal Recycling Sp. z o.o., 32-540 Trzebinia, Poland; mpartyka@unilab.biz (M.P.); \\ ksaluga@unimetalrecycling.pl (K.S.) \\ * Correspondence: ngenerowicz@min-pan.krakow.pl
}

Citation: Generowicz, N.; Kulczycka, J.; Partyka, M.; Saługa, K. Key Challenges and Opportunities for an Effective Supply Chain System in the Catalyst Recycling Market-A Case Study of Poland. Resources 2021, 10, 13. https://doi.org/10.3390/ resources10020013

Academic Editors: Xianlai Zeng and Eveliina Repo

Received: 30 September 2020

Accepted: 4 February 2021

Published: 9 February 2021

Publisher's Note: MDPI stays neutral with regard to jurisdictional claims in published maps and institutional affiliations.

Copyright: (C) 2021 by the authors. Licensee MDPI, Basel, Switzerland. This article is an open access article distributed under the terms and conditions of the Creative Commons Attribution (CC BY) license (https:// creativecommons.org/licenses/by/ $4.0 /)$.

\begin{abstract}
Increasing public awareness about low emission and stricter standards has a significant impact on the industry. The use of catalytic converters provides one of the solutions to the problem of lowering the amount of exhaust fumes. As most catalytic converters contain a combination of the three metals $\mathrm{Pt}, \mathrm{Pd}$ and $\mathrm{Rh}$, the manufacture of catalysts for automobiles is the largest sector of demand for and consumption of PGMs (platinum group metals). In Poland, the recycling system for catalysts is still in the development stage, but there is a significant trend of increase mainly due to EU policy on the circular economy. Due to frequent legal changes, the market is not fully transparent and the price for used catalysts can vary significantly. Therefore, apart from the recycling technology itself, it is important for the company to have a transparent method of testing the catalysts. The aim of this article was to identify the key opportunities and challenges to improving the catalyst recycling system in Poland. The organisational solutions have been analysed to show that an effective system could be implemented by creating a network between suppliers and customers with the use of good laboratory equipment and IT applications. The article defines the key opportunities and challenges such as the need to invest in an innovative laboratory and software for assessment of chemical composition and economic value of waste. A great opportunity for the development of this sector is the high demand for critical raw materials such as PGMs, which can be supported by research and development $(\mathrm{R} \& \mathrm{D})$ projects.
\end{abstract}

Keywords: catalyst; platinum group metals; recycling; supply chain system

\section{Introduction}

Raising public awareness about air pollution and stricter standards and regulations [1] has a significant impact on industry, transport and energy production. The use of catalytic converters [2] provides one of the solutions to the problem of minimising the dispersion of toxic compounds and lowering the amount of exhaust fumes emitted to the atmosphere during the combustion of fuels in passenger cars, trucks and buses, and many other types of machinery [3]. As most catalytic converters contain a combination of the three metals, $\mathrm{Pt}, \mathrm{Pd}$ and $\mathrm{Rh}[4,5]$, the manufacture of catalysts for automobiles is the largest sector of demand for and consumption of PGMs (platinum group metals) [6-8]. Most studies and expert appraisals predict that future demand for these critical metals will increase [9]. Due to the global economic recession related to COVID-19, analyses of the impact on the catalyst market were also carried out. Estimates showed that there is no potential short-term impact on PGM loadings resulting from government initiatives or catalyst fitment strategies at individual companies [10]. It is likely that financial stress due to the COVID-19 crisis will 
motivate car companies to take a fresh look at opportunities to reduce the cost of their exhaust after treatment systems [11,12].

Over the past two decades, many countries around the world have developed and implemented long term solutions to environmental problems $[10,11]$ designed to minimise the impact of the growing number of cars. One solution is the organisation of an end-of-life car recycling network that is now an integral part of the global automotive industry [13]. The U.S. Geological Survey reports show an increasing worldwide trend towards the recovery of PGMs from end-of-life vehicles [14]. Zhang et al., Puig and Alvarado are focusing on the development of technological solutions focusing on individual metals, i.e., the recycling of palladium or platinum. Saternus et al. are focusing on an innovative method of using an mhd pump for recovering platinium from a used catalyst [15]. Prasetyo and Anderson are focusing on the recovery of platinium group elements using acidic fusion and leaching [16]. Yakoumis et al. predict an increasing demand for PGMs in the years to come due to the stringent EU standards for emissions controls imposed on car manufacturers [17]. However, the introduction of electric cars and fuel cell vehicles on the market may reduce the profitability of recycling of PGMs from catalysts in the future. On the other hand, the lack of deposits of these metals in Europe and the current high demand for them, especially by the automotive industry, makes PGMs critical raw materials [18]. Therefore, their elimination from electric cars may be a good solution, among others, from the point of view of securing their supply [19]. It is necessary to look for new recycling technologies that are economically viable and environmentally friendly [20]. Especially since the use of PGMs does not only end with catalysts. They are also used in electronics and medicine (as elements of anticancer drugs) and therefore their demand is high in other sectors as well.

The main drivers for the development of the design of the recycling network were legal regulations [21,22] and economic conditions [23]. In the EU, the common rules for handling waste from end-of-life cars, including extended producer responsibility (EPR), were introduced by Directive 2000/53/EC on end-of-life cars [24]. They not only caused an increase in the production of the technology of PGM recovery from catalysts, but also created a market for it. The literature focuses on the development of technological solutions for individual metals, i.e., the recycling of palladium [25] and platinum [26], on processes, i.e., higher extraction efficiency (99.5\%) and purity (98.5\%) [27], and on efficient reclamation [28]. Only one article by Ferella is saying that the correct and environmentally-friendly management of such catalysts is required [29]. In Poland the recycling system for catalysts is still in the development stage, but there is a significant trend to an increase mainly due to EU policy on the circular economy [30]. Due to frequent legal and technological changes [31], the market is not fully transparent and the price for used catalysts varies significantly [32]. The price depends on the existing precious metal content of the catalyst. According to the Unimetal Recycling (UMR) Catalogue, the value of a catalyst is estimated to be between 5 EUR and 4000 EUR. Therefore, apart from the recycling technology itself, it is important for the company to have a transparent method of testing the catalysts that determines the value of the product in an equitable, clear and transparent way [33]. Thanks to such solutions, the company becomes reliable and the level of catalyst recycling in a given area increases [34,35].

The aim of this article is to identify the key opportunities for and challenges to improving the catalyst recycling system in Poland. The legal, market, technological, economic and, above all, organisational solutions have been analysed to show that an effective system could be implemented by creating a network between suppliers and customers with the use of good laboratory equipment with dedicated IT applications. This article presents an example of good practice by Unimetal Recycling (UMR) company that has both used technology for metal recovery and also written the software and used it to calculate the prices of used catalysts based on the LBMA (London Bullion Market Association) prices for platinum and palladium [36] and estimated the metal content, catalyst model and degree of wear. It aims to show a clear and transparent strategy based on 
Porter's value chain management concept which permits better cooperation with suppliers and enables a symbiosis to develop throughout the whole supply chain. Such good cooperation in the value chain also creates a demand for joint research and development $(R \& D)$ projects and close cooperation with universities and enables an increase in economic and resource efficiency.

\section{Materials and Methods}

Figure 1 shows the conduct chain in the analysis of the catalyst recycling market. It is a schematic representation of the way data was collected to analyse the catalyst market and which of its segments requires the greatest development in Poland. Thanks to this scheme, it is easier to illustrate the idea of supply chain.

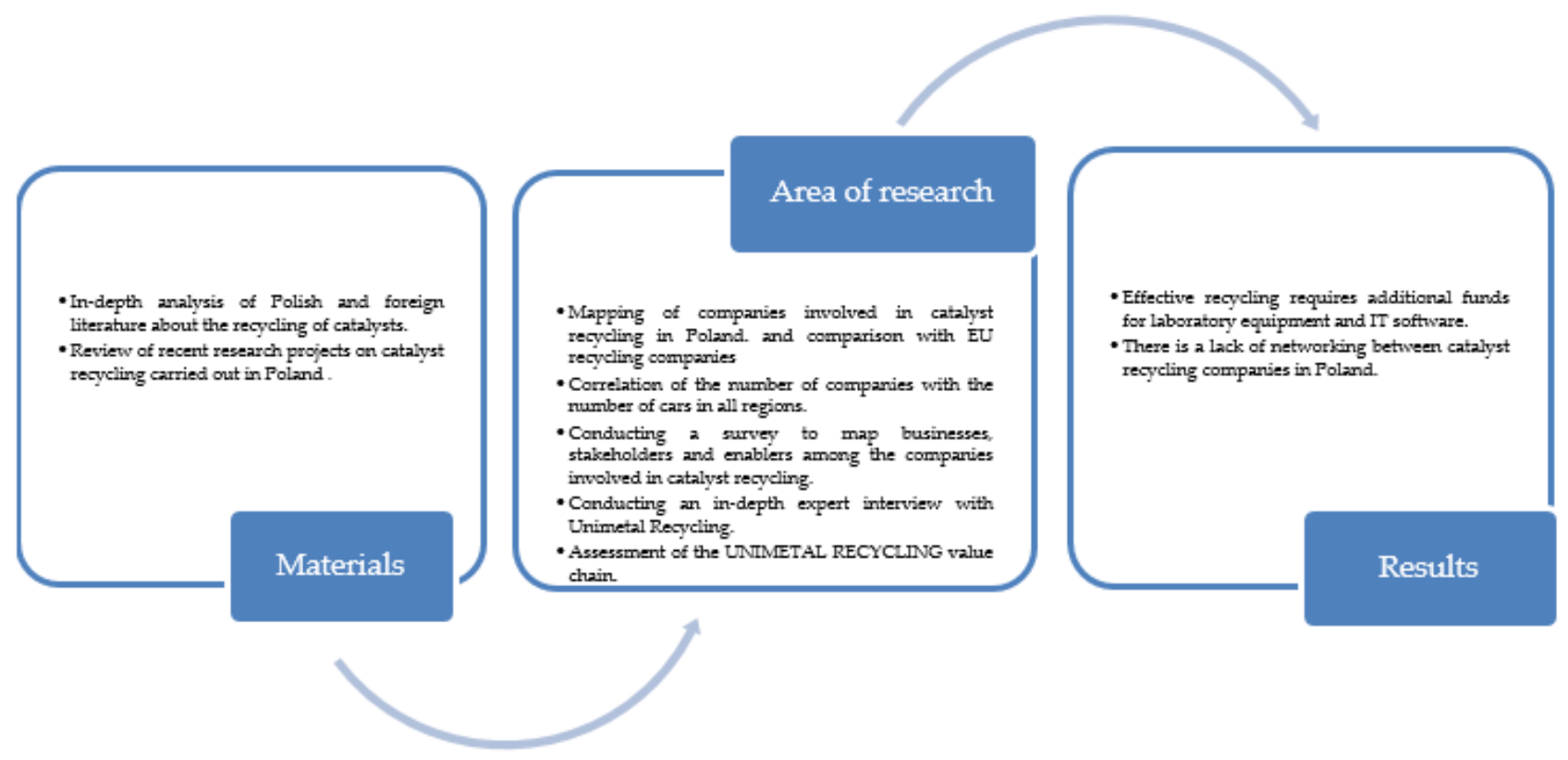

Figure 1. The conduct chain in the analysis of the catalyst recycling market.

\subsection{Materials}

First, an analysis of the catalyst market (2015-2020) was carried out, focusing on cooperation in the value chain and industrial symbiosis with in-depth analysis of Polish and foreign literature. It allowed the technological challenges, environmental hotspots, legal constraints and economic instruments promoting cooperation and networking to be identified. Moreover, in order to analyse future trends in catalyst technology and the market in Poland, a review was carried out of recent R\&D projects which obtained financial support from different research funds in Poland (more information in Supplementary Materials). This shows that they mostly focus on the improvement of catalyst quality or the development of new recycling technology; none look at substitution. There is no official network or association in Poland, but some companies are members of the Waste Recycling and Management Cluster-a key national cluster.

\subsection{Area of Research}

The area of analysis of the catalyst recycling market in Poland is determined by the geographical distribution of the most important large companies specialising in catalyst recycling, which are mainly located in the southern half of Poland (Figure 2). Mapping companies dealing with catalyst recycling shows that most companies are located near the German and Ukrainian border, whereas UMR is the only one in the southern part of Poland. 


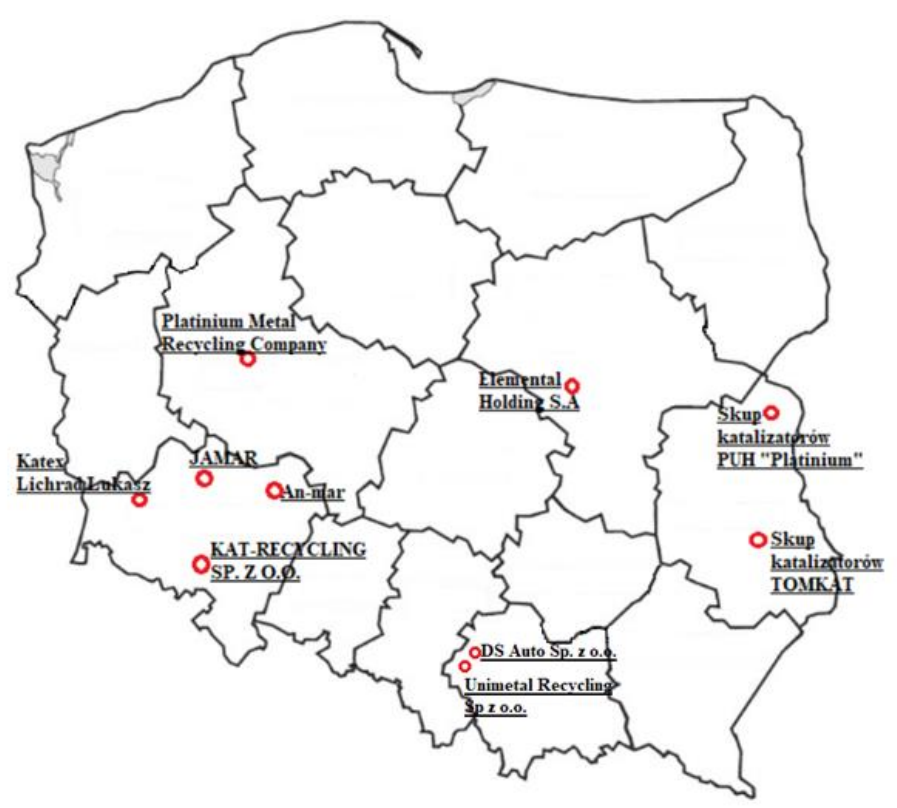

Figure 2. Location of the catalyst recycling companies in Poland divided into voivodeships (source: own work based on companies' webpages).

Most of these companies operate with Polish capital and most of them were created in the last 10 years (Table 1 ).

Table 1. Registration data and legal structure of the most important catalyst recycling companies in Poland.

\begin{tabular}{|c|c|c|c|c|}
\hline & Company Name & Date of Registration & Legal Form & Source \\
\hline 1 & An-mar & 2007-01-15 & trading business & panoramafirm.pl \\
\hline 2 & $\begin{array}{l}\text { Skup katalizatorów } \\
\text { PUH Platinum }\end{array}$ & $2008-12-18$ & general partnership & $\begin{array}{l}\text { https:/ / www.platinum- } \\
\text { katalizatory.pl/ }\end{array}$ \\
\hline 3 & JAMAR & 2010-08-11 & limited partnership & https://katalizatory-skup.pl/ \\
\hline 4 & Elemental Holding S.A. & 2011-01-13 & joint-stock company & https://elemental.biz/ \\
\hline 5 & DS Auto Sp. z o.o & 2011-01-28 & limited partnership & $\begin{array}{c}\text { https: } \\
\text { // katalizatorychrzanow.pl/ }\end{array}$ \\
\hline 6 & $\begin{array}{l}\text { PLATINIUM Metal } \\
\text { Recycling Company }\end{array}$ & 2011-12-07 & limited partnership & https:/ / catalystrecycling.pl/ \\
\hline 7 & $\begin{array}{c}\text { Skup katalizatorów } \\
\text { TOMKAT }\end{array}$ & 2014-02-06 & $\begin{array}{l}\text { limited liability } \\
\text { company }\end{array}$ & http:/ / www.tomkat-lublin.pl \\
\hline 8 & $\begin{array}{l}\text { Unimetal Recycling Sp } \\
\text { z o.o. }\end{array}$ & 2014-05-09 & limited partnership & https:/ / unimetalrecycling.pl \\
\hline 9 & $\begin{array}{l}\text { KAT-RECYKLING SP Z } \\
\text { O.O. }\end{array}$ & $2015-10-22$ & limited partnership & $\begin{array}{c}\text { https: } \\
\text { //www.kat-recykling.pl/ }\end{array}$ \\
\hline 10 & $\begin{array}{c}\text { KATEX Lichorad } \\
\text { Łukasz }\end{array}$ & $2017-10-25$ & limited partnership & https://indexfirm.pl \\
\hline
\end{tabular}

Source: own work based on companies' webpages.

The market for recycling catalysts in Poland will develop as the number of cars reaches 30 million. As of the end of June 2020, there are 29,656,238 vehicles of all kinds registered in Poland (of which 3,338,166 are trucks and 1,428,299 motorcycles). To compare with a decade ago, the total number of cars in Poland was then estimated as 22,024,697 [37].

During the carrying out of the Innocat Project (KIC Raw Materials), a survey was carried out in Poland during the last quarter of 2018 by means of pilot monitoring and on-site interviews to map businesses operating in the field, stakeholders and enablers with innovation capacity/orientation. From the database of 60 companies found to be dealing with the buying and recycling of catalysts, 25 companies took part in the analysis. In total, 
$90 \%$ of respondents declared his/her company was a small one. The results of the analysis showed that

- $80 \%$ have awareness of developments in the field of replacement/modernisation of catalysts in vehicles,

- $70 \%$ pointed out that the demand for replacement catalysts is rather average or limited,

- $\quad 90 \%$ indicated equity as the company financing model, and the remaining $10 \%$ pointed to EU funds and other types of subsidies.

Moreover, the results of the analysis showed that companies are not considering cooperation with other companies and research organisations, although $40 \%$ would be interested in a strategic alliance. In addition, one of the questions was to ask if they could name the company which is the best developed for creating a system of customers and suppliers in Poland, and 80\% from respondents pointed to Unimetal Recycling (UMR), specialised strictly in catalyst recycling.

Analysing the way foreign companies work, it is clear that catalyst recycling is usually only a part of their variety of recycling activities. Therefore, on the EU market there are some global companies, i.e., Umicore or Elemental Holding dealing with urban mining and recycling, and regional ones dealing with recycling of catalysts from different sources, whereas Unimatal Recycling is focused strictly on automotive catalyst recycling. Activities of a Polish company were compared with the chosen EU recycling companies (Table 2).

Table 2. The activities of chosen EU recycling companies.

\begin{tabular}{|c|c|c|c|c|}
\hline & Company Name & Scope & Range & Source \\
\hline 1 & Umicore & $\begin{array}{l}\text { It is a global materials technology and recycling } \\
\text { group. It focuses on application areas where its } \\
\text { expertise in materials science, chemistry and } \\
\text { metallurgy makes a real difference. Its activities are } \\
\text { organised in three business groups: } 1 \text {. Catalysis, } 2 \text {. } \\
\text { Energy and Surface Technologies and 3. Recycling. }\end{array}$ & Worldwide & $\begin{array}{c}\text { https: } \\
\text { //www.umicore.com/ }\end{array}$ \\
\hline 2 & Elemental Holding & $\begin{array}{l}\text { Elemental Holding S.A. invests in entities dealing } \\
\text { with urban mining and recycling. Companies } \\
\text { belonging to the ELEMENTAL Group operate within } \\
\text { the framework of four business lines: recycling of } \\
\text { spent automotive catalysts (SAC), recycling of waste } \\
\text { electrical and electronic equipment (WEEE), } \\
\text { recycling of printed circuit boards (PCB), recycling of } \\
\text { non-ferrous metal scrap (non- ferrous). }\end{array}$ & Worldwide & $\begin{array}{l}\text { https: } \\
\text { //elemental.biz/en/ }\end{array}$ \\
\hline 3 & Johnson Matthey & $\begin{array}{l}\text { They are organised into four sectors, aligned to the } \\
\text { needs of customers and the global challenges. They } \\
\text { are structured internally into the groups of Clean Air, } \\
\text { Efficient Natural Resources, Health, New Markets. }\end{array}$ & Worldwide & www.matthey.com \\
\hline 4 & Remondis PMR B.V. & $\begin{array}{l}\text { It is divided into three main areas-recycling, } \\
\text { services and water-and the individual companies } \\
\text { within the REMONDIS Group have been organised } \\
\text { to reflect this structure. However, it is not always } \\
\text { possible to draw a clear-cut line between recycling, } \\
\text { services and water so that the three often overlap. } \\
\text { Many of REMONDIS companies, therefore, provide } \\
\text { services from two or even all three areas. }\end{array}$ & Worldwide & $\begin{array}{l}\text { https://www. } \\
\text { remondis-katalysator- } \\
\text { recycling.de/en/ }\end{array}$ \\
\hline 5 & $\begin{array}{l}\text { MAIREC Edelmet- } \\
\text { allgesellschaft } \\
\mathrm{mbH}\end{array}$ & $\begin{array}{l}\text { The company recycles automotive catalysts, } \\
\text { industrial catalysts, electronic scrap, sweeps and } \\
\text { concentrates and other industrial waste. }\end{array}$ & Germany & $\begin{array}{c}\text { https: } \\
\text { //www.mairec.com/ }\end{array}$ \\
\hline 6 & MONOLITHOS & $\begin{array}{l}\text { In addition to recycling, the company deals with the } \\
\text { production of catalysts. }\end{array}$ & Greece & $\begin{array}{l}\text { https: } \\
\text { //www.monolithos- } \\
\text { catalysts.gr/en/ }\end{array}$ \\
\hline
\end{tabular}




\subsection{Methodology}

The article uses the Porter value chain method to evaluate the way UMR works. The value chain concept used here is based on the process view of organisations, the idea of seeing the organisation as a system made up of subsystems each with its own inputs, transformation processes and outputs [34]. Based on the method of Porter (1985), the primary activities of UMR are:

- Inbound logistics-involving networking with suppliers and all the activities required to receive, analyse and recycle catalysts.

- Operations-these are all activities related to the preparation of the catalyst for recovery of PGMs.

- Outbound logistics-include all the activities required to collect and store data about the catalyst available on the market.

- Marketing and sales-activities to inform customers about products and services, induce buyers to purchase them and facilitate their purchase.

- Service-includes all the activities required to keep the process of recycling of the catalyst working effectively for the customer after he/she has decided to sell it.

- Secondary activities are:

- Procurement-the acquisition of inputs, or resources, for the company based on their own IT software.

- Human resource management—consists of all activities involved in recruiting, hiring, training, developing, compensating (UMR provides corporate social responsibility).

- Technological development-pertains to the equipment, hardware, software, procedures and technical knowledge which is used in the technology for recycling the catalyst but also in the laboratory during the analysis of the catalyst and also the software specially prepared by UMR.

- Infrastructure-serves the company's needs and ties its various parts together and consists of functions and departments.

The general scheme of such functionality and the role of procurement infrastructure with their own IT software is shown in Figure 3.

\section{Primary Activities}

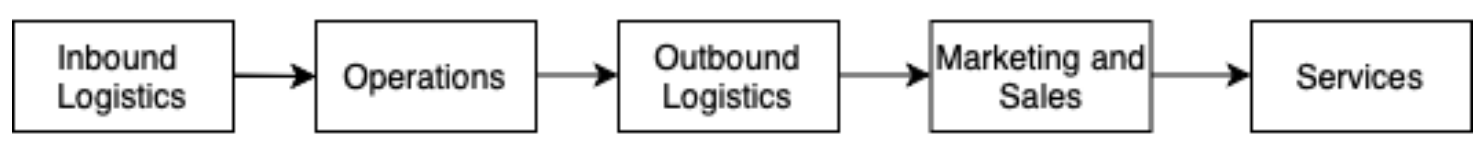

The Value Chain

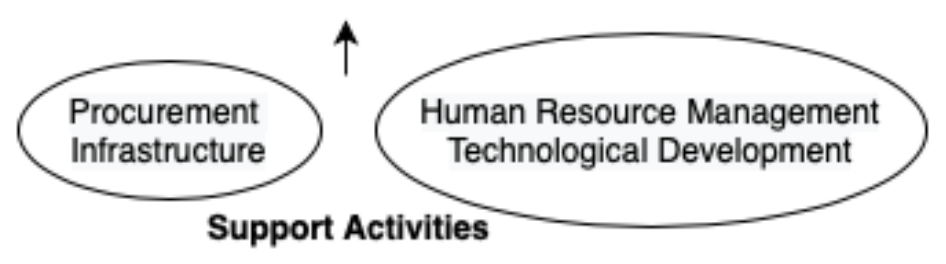

Figure 3. The value chain for Unimetal Recycling [own source based on [38].

\subsection{The Importance of Transparency in Catalyst Analysis-Case Study of Unimetal Recycling}

UMR is a leading company carrying out car catalyst processing in Poland. UMR has been engaged in the purchase and processing of automotive catalysts on world markets and in Poland. The company collects car catalytic converters with ceramic and metal cores and also ceramic monoliths in powder or in pieces, paying a price for them (the price is based on the actual assayed quantity of precious metals they contain). Over twenty years of experience in the purchasing of catalytic converters has enabled UMR to become the leader in this field in this part of Europe. 
UMR cooperates with companies around the globe, both large and small. The company purchases and processes used ceramic catalytic converters and the monolith contained in them, as well as metal catalytic converters from cars. The main goal of the company is to recover as many precious metals $(\mathrm{Pd}, \mathrm{Rh}$ and $\mathrm{Pt})$ as possible from the material supplied. It should be noted that UMR is a company that provides reliable, legal solutions-all operations complying with Polish and EU regulations. High levels of quality are important to accomplish the company's business objectives since well-documented processes reduce errors, improve productivity and increase profits. The added value is qualified personnel.

In this case, it is very important that UMR has a large network of suppliers and contractors. UMR cooperates with almost 100 points (suppliers and contractors) in Poland and over 30 abroad. In Poland, partner points are located in each voivodeship. A large proportion of the vehicle disassembly stations in Poland forward exhausted catalysers for further processing to UMR.

The purchase of used catalysts takes place almost everywhere in Poland-UMR has established service points in most voivodships and catalysers can also be collected from customers using UMR's own car fleet. An initial quote can be obtained (from partners) by e-mail, telephone or their website. Valuations can be prepared in a very short time; it is not even necessary to have the numbers of the catalysts because the qualified team can verify the model of the device on the basis of their existing knowledge, e.g., based on the photo (it should be noted that the best form of valuation is on-site valuation after the material has been brought to homogeneous form).

Catalysts are classified according to transparent, understandable criteria, and the company has all the permits provided for in the relevant legal acts. UMR is one of the few organisations in Poland that is authorised to collect and process waste with the code 160801 and 160803 . The beginning of the code of the waste record (16 08) refers to used catalysts. The code ending in (01) defines devices containing gold, silver, rhenium, rhodium, palladium, iridium or platinum (those contaminated with hazardous substances are excluded), while the code ending in (03) defines devices containing transition metals or their compounds, apart from those that are dangerous. Using the above-mentioned permits, the company can cooperate with dismantling and vehicle dismantling stations from all over Poland and Europe. The catalyser recycling process begins with a selective collection process. The company cooperates with many partner points throughout the country and also outside the country, currently mainly in Europe but also in Africa and Asia.

After the delivery of catalysts to UMR, each batch is marked so that it can be specifically assigned (customer identification). Then, an employee measures the weight of the lot and prepares a preliminary weight report. Later, the ceramic monolith is separated from other parts of the catalyst, i.e., the casing and thermal insulation (mesh), using hydraulic shears. The pre-crushed ceramic material goes to the chute and the metal parts are stored in special containers. Next, the monolith is passed to further processing, i.e., re-weighing and the process of grinding and homogenisation, and representative samples are taken by the employee to separate small containers (this is a sample for laboratory analysis).

The company assumes that recycling technology is important for the company's development, however, the value added is their own IT system of catalyst tested. Such system is clear, transparent and more reliable for every entity in the value chain. In such a way long term trust has already been built with a lot of customers who treat the whole catalyst recycling system in a correct and controllable way. Therefore, apart from the method of recovery of PGMs from the catalysts themselves, UMR has invested in building a professional laboratory for analysing the composition of elements in a given catalyst. This is a very important aspect, as there is a huge range of different types of catalyst available on the market, which makes it very difficult to test each one of them thoroughly. Testing of catalysts is carried out using a number of advanced technologies.

In the first stage, X-ray fluorescence spectroscopy (XRF) is used to determine the elements ( $\mathrm{Pt}, \mathrm{Rh}$ and $\mathrm{Pd})$ in the monolith. This is a technique that allows qualitative and quantitative analysis of the elemental composition of the sample. The measurement can be 
performed quickly and non-destructively. An equivalent technique is ICP-MS (inductively coupled plasma mass spectrometry) after sample preparation in the microwave mineraliser. This is longer and destructive technique. After these measurements are carried out, the analysis then proceeds to the recovery of the elements. The sorting process takes place according to the type of monolith core (ceramic or metal). First, the metal cover is torn or cut and the net-the insulating material-is removed. Then, the ceramic monolith is removed and crushed into fine dust in ball mills. Using such a grinding technique, it is possible to precisely measure the precious metal content of the material being prepared. The final process is refining. Depending on the notching, bars are smelted or a metallic powder is obtained. Moreover, the company has its own software for the valuation of more than 9000 catalysts which is currently being updated. Such thorough analyses make the company more reliable and the catalyst recycling process transparent. This makes it possible to establish a special kind of symbiosis and cooperation in the supply chain, which is crucial for development nowadays. As of today, UMR is accepting 3000 catalysts per day for recycling (data for 2019).

The transparency of all stages is maintained at all times. This is a very important matter in relation to their contacts with contractors, often associated with direct participation of the person concerned (while maintaining appropriate security principles as well as confidentiality and protection of the interests of other clients) in both the material homogenisation processes and laboratory tests. The devices purchased are classified according to transparent, understandable criteria, and after the tests are carried out in the laboratory, the client receives a calculation that takes into account the current quotations of currencies and precious metals on world exchanges (with the possibility of checking the quotations on the exchanges themselves). Furthermore, the client receives a sample (homogeneous material) which allows them to verify the results in an accredited laboratory.

The group of UMR clients is constantly expanding. The company uses modern technological solutions and employs qualified personnel. The main goal is to support and connect people and enterprises that want to introduce positive changes in both the immediate and more distant environment. This approach shows that it is possible to conduct business related to the processing of catalysts transparently while maintaining principles of corporate social responsibility (CSR).

\section{Results and Discussion}

With reference to the issues discussed above, a research problem was presented whose aim was to develop symbiosis and cooperation in a supply chain between suppliers and customers throughout Poland.

Zhang et al. note that future demand for these critical metals will increase in the years to come [1]. Molnár and Papp [10] show the development and implementation solutions that would minimise the impact of the growing number of cars on the environment, confirmed by the U.S. Geological Survey data, i.e., increasing worldwide trends in relation to the recovery of PGMs from end-of-life cars [13]. Yakoumis et al. predict the increasing demand for PGMs in the years to come [17]. Zhang et al., Puig and Alvarado analyse the development of technological solutions for individual metals, i.e., the recycling of palladium or platinum $[25,26]$. In Poland the catalyst recycling market is relatively new. Companies located in Poland have been on the market for up to 10 years (Supplementary Materials). As shown in Figure 2, they are only located in a few provinces. This provides opportunities for further development of the market in other areas in Poland.

After the results of the analysis, the problem of creating supplier networks and establishing cooperation proved to be the most important issue. Thanks to the respondents answers concerning UMR, an interview was conducted with the company, which showed how the whole company functions and how important networking is in order to expand market contacts [33]. In addition, conducting the survey of recycling companies to map business enterprises, stakeholders and enablers with innovation capacity/orientation in Poland has shown that only $40 \%$ would be interested in a strategic alliance. This shows 
how difficult it is to organise the establishment of a recycling management system in Poland. Each company focuses its attention solely on the local market, which limits its development possibilities. Interviews with experts from UMR have shown that the company's transparency as well as the establishment of a fully equipped laboratory and its own software allow it to expand its supply network. UMR, by creating an ever-wider group of suppliers, proves that catalyst recycling is not only concerned with the technology of obtaining a monolith from a catalyst, but also the company's transparency. This translates into the fact that suppliers supply their products to the most transparent recycler.

As far as future market trends are concerned, there are key opportunities for UMR in the growing overall demand for $\mathrm{Pt}, \mathrm{Pd}$ and $\mathrm{Rh}$, which is confirmed by Zhang [25], but the challenge predicted by the U.S. Geological Survey lies in the increasing recycling and recovery of these metals, and therefore, UMR should invest and look for new technologies [11]. It should also be emphasised that actions related to the recovery of PGMs from catalysts are ideally suited for a circular economy [39]. The European Commission is currently putting strong focus on developing this topic. The implementation of recovery of raw materials from secondary sources is an ideal example of circularity. This is an important aspect of the analysis, as the European Commission points out that with a new industrial strategy, a transformation leading to climate neutrality can replace the current dependence on fossil fuels by dependence on raw materials [40,41].

Comparing work of UMR and an exemplary foreign company such as Elemental Holding or Umicore, which are the leaders in the market [42,43], it is possible to see that despite the scale of its operations, UMR could also, due to the support of European Funds, create a research and development center and IT software. Taking into consideration the key opportunities for UMR, there is continuous improvement of IT systems, which ties into client demand and market changes, whereas key challenges lie in the creation of a network covering not only part of Poland but also cooperation with foreign partners from all over the world. Also taking legal and policy aspects into consideration, the key opportunities are the implementation of the key challenges for a circular economy, a fast pace of changes in legislation and stricter environmental conditions.

Overall, following the analysis of the UMR company as well as the use of Porter's value chain management method, which very well describes the way the company operates, the most important conclusions are that there is a noticeable lack of networking between catalyst recycling companies in Poland and also that it is very important to provide additional funds for laboratory equipment and IT software.

During the work, the following limitations for market development were identified:

1. Difficult access to identify the entities in the whole supply chain in Poland. There are a lot of micro companies which collect waste, including catalysts, which are not promoting their activities on the Internet (do not have webpage) as they work in internal and informal networks.

2. Collecting of data about waste was time consuming as they were reported to the voivodeship database. Nowadays, a central database available in Poland.

3. The time and permission for new investment, even in recycling technology, is time consuming, due to environmental procedure, including public consultations.

4. The results of cooperation between science and recycling companies are not widely published.

\section{Conclusions}

The article discusses the key challenges and opportunities for the development of catalyst recycling in Poland. The analysis of the topic has allowed for the specification of these two aspects, which are summarised below.

The challenges facing the catalyst recycling market in Poland are:

1. Most studies and expert appraisals predict that future demand for these critical metals will increase, which will result in a shortage of supply of these metals if there is no recycling from major secondary sources. 
2. The main drivers for the development of the design of the recycling network are legal regulations and economic conditions, but also the declining amount of primary sources of these suppliers.

3. In Poland, the recycling system for catalysts is still developing, but there is a significant trend to an increase mainly due to EU policy on the circular economy.

4. Review of projects showed that they mostly focus on the improvement of catalyst quality or the development of new recycling technology; none of them focus on innovation and cooperation in the whole supply chain. There is no official network or association in Poland, but some companies are members of the Waste Recycling and Management Cluster-Key National Cluster of Poland.

5. The results of the survey showed that companies are not considering cooperation with other companies and research organisations, although $40 \%$ would be interested in a strategic alliance.

6. Because of frequent technological and legal changes, the market is not transparent and the price for used catalysts varies significantly. Moreover, some catalysts are offered on the "black market".

7. It is important for the companies to have a transparent method of analysing the catalysts that determines the value of the product in a clear and equitable way, however, it requires significant investment.

The opportunities that could help in the development of the catalyst recycling market in Poland:

1. As catalytic converters contain mainly a compound of the three metals $\mathrm{Pt}, \mathrm{Pd}$ and $\mathrm{Rh}$; the manufacture of catalysts for automobiles is the largest sector of demand for and consumption of PGMs.

2. If the COVID-19 pandemic affected the PGM supply from primary and secondary resources as well as demand in 2020, the estimates show that there was only a shortterm impact connected with temporary plant closures.

3. It is possible that financial stress due to the COVID-19 crisis will motivate car companies to take a fresh look at opportunities to reduce the cost of their exhaust after treatment systems.

4. Effective system could be implemented by creating a network between suppliers and customers with the use of good laboratory equipment with dedicated IT applications.

5. Such good cooperation in the value chain also creates a demand for joint $R \& D$ projects and close cooperation with universities and enables an increase in economic and resource efficiency.

6. In Poland, the development of catalyst recycling is going in the right direction, especially when we compare it to the largest companies in the world, although not every company can take advantage of this situation.

7. The development of catalyst recycling in Poland fits perfectly into the topic of circular economy. Such activities can be supported by the European Commission in various $R \& D$ projects in the future.

8. There is growth potential in the market for very specialised companies in a semicompetitive market with the dominance of large international companies.

The analysis of this topic has also allowed us to conclude that it is necessary to conduct further research in the field of sustainable and transparent supply chain management on the catalyst market in Poland. More advanced recovery techniques for waste materials are needed.

The European catalyst market is dominated by large companies that specialise in many areas, and catalyst recycling is just one of them. UMR had to enter a market where there is already strong competition in Europe. By investing in a laboratory and in software for valuing catalysts, UMR has shown that reliability and transparency are most important for them. In addition, the company also invests in its personnel and employs the local community to support the development of the local region. All these activities show that the company has a long-term vision for sustainable business. 
Supplementary Materials: The following are available online at https:/ /www.mdpi.com/2079-927 6/10/2/13/s1. Table S1: An overview of projects relating to catalyst recycling carried out in Poland.

Author Contributions: Conceptualization, J.K. and N.G.; methodology, J.K. and N.G.; validation, N.G., J.K., K.S. and M.P.; formal analysis, J.K., K.S., M.P. and N.G.; investigation, J.K. and N.G.; resources, K.S., M.P. and N.G.; data curation, N.G. and M.P.; writing-original draft preparation, N.G writing-review and editing, J.K.; visualization, J.K. and N.G.; supervision, J.K and N.G.; project administration, N.G., J.K., K.S. and M.P. All authors have read and agreed to the published version of the manuscript.

Funding: This research was funded by the Polish National Agency for Academic Exchange (NAWA) as part of the project "International cooperation for Rational Use of Raw Materials and Circular Economy" (COOPMIN) which is conducted in the Division of Strategic Research in the MEERI PAS project no. PPI/APM/2018/1/00003 and the EIT KIC Raw Materials, Innovative CRM substitution technology for public authorities' vehicle catalysts (INNOCAT) project, number 18344.

Institutional Review Board Statement: Not applicable.

Informed Consent Statement: Informed consent was obtained from all subjects involved in the study.

Data Availability Statement: The data underlying this article are available in the open license and in its online supplementary material.

Conflicts of Interest: The authors declare no conflict of interest.

\section{References}

1. Ding, Y.; Zhang, S.; Liu, B.; Zheng, H.; Chang, C.C.; Ekberg, C. Recovery of precious metals from electronic waste and spent catalysts: A review. Resour. Conserv. Recycl. 2019, 141, 284-298. [CrossRef]

2. Resano, M.; Flóres, M.; Oeralt, I.; Margui, E. Determination of palladium, platinum and rhodium in used automobile catalysts and active pharmaceutical ingredients using high-resolution continuum source graphite furnace atomic absorption spectrometry and direct solid sample analysis. Spectrochim. Acta Part B At. Spectrosc. 2015, 105, 38-46. [CrossRef]

3. Olejnik, T.P.; Sobiecka, E. Utilitarian Technological Solutions to Reduce $\mathrm{CO}_{2}$ Emission in the Aspect of Sustainable Development. Probl. Sustain. Dev. 2017, 12, 173-179.

4. Knobloch, V.; Zimmermann, T.; Gößling-Reisemann, S. From criticality to vulnerability of resource supply: The case of the automobile industry. Resour. Conserv. Recycl. 2018, 138, 272-282. [CrossRef]

5. Trinh, H.; Lee, J.; Suh, Y.; Lee, J. A review on the recycling processes of spent auto-catalysts: Towards the development of sustainable metallurgy. Waste Manag. 2020, 114, 148-165. [CrossRef]

6. Ding, Y.; Zheng, H.; Zhang, S.; Liu, B.; Wu, B.; Jian, Z. Highly efficient recovery of platinum, palladium, and rhodium from spent automotive catalysts via iron melting collection. Resour. Conserv. Recycl. 2020, 155, 104644. [CrossRef]

7. Asimellis, G.; Michos, N.; Fasaki, I.; Kompitsas, M. Platinum group metals bulk analysis in automobile catalyst recycling material by laser-induced breakdown spectroscopy. Spectrochim. Acta Part B At. Spectrosc. 2008, 63, 1338-1343. [CrossRef]

8. Wei, X.; Liu, C.; Cao, H.; Ning, P.; Jin, W.; Yang, Z.; Wang, H.; Sun, Z. Understanding the features of PGMs in spent ternary automobile catalysts for development of cleaner recovery technology. J. Clean. Prod. 2019, 239, 118031. [CrossRef]

9. Zhang, S.; Ding, Y.; Liu, B.; Chang, C.C. Supply and demand of some critical metals and present status of their recycling in WEEE. Waste Manag. 2017, 65, 113-127. [CrossRef]

10. Molnár, A.; Papp, A. Catalyst recycling-A survey of recent progress and current status. Coord. Chem. Rev. 2017, 349, 1-65. [CrossRef]

11. Cowley, A.; Bloxham, L.; Brown, S.; Cole, L.; Cowley, A.; Fujita, M.; Girardot, N.; Jiang, J.; Raithatha, R.; Ryan, M.; et al. The Pgm Market Report. 2020. Available online: http:/ / www.platinum.matthey.com/services/market-research/pgm-market-reports (accessed on 22 September 2020).

12. Habib, K.; Sprecher, B.; Young, S.B. COVID-19 impacts on metal supply: How does 2020 differ from previous supply chain disruptions? Resour. Conserv. Recycl. 2021, 165, 105229. [CrossRef]

13. Tsai, W. Promoting the Circular Economy via Waste-to-Power (WTP) in Taiwan. Resources 2019, 8, 95. [CrossRef]

14. Wilburn, D.; Bleiwas, D. Platinum-Group Metals-World Supply and Demand. 2005. Available online: https://www.researchgate. net/publication/267298042_Platinum-Group_Metals-World_Supply_and_Demand (accessed on 23 September 2020).

15. Saternus, M.; Fornalczyk, A.; Gąsior, W.; Dębski, A.; Terlicka, S. Modifications and Improvements to the Collector Metal Method Using an mhd Pump for Recovering Platinum from Used Car Catalysts. Catalysts 2020, 10, 8080. [CrossRef]

16. Prasetyo, E.; Anderson, C. Platinum Group Elements Recovery from Used Catalytic Converters by Acidic Fusion and Leaching. Metals 2020, 10, 485. [CrossRef]

17. Yakoumis, I.; Moschovi, A.; Panou, M.; Panias, D. Single-Step Hydrometallurgical Method for the Platinum Group Metals Leaching from Commercial Spent Automotive Catalysts. J. Sustain. Metall. 2020, 6, 259-268. [CrossRef] 
18. Hakan, M.M. A new approach to recover platinum-group metals from spent catalytic converters via iron matte. Resour. Conserv. Recycl. 2020, 159, 104891. [CrossRef]

19. Loutatidou, S.; Sanchez, B.F.; Festa, E.; Akil, N. Value Chain Stakeholders Analysis. PGMs Recovery Using Secondary Raw Materials. Report from the Platirus Project. 2016.

20. Trębacz, H.; Michno, P. The evaluation of Platinum Group Metals (PGMs) and their recovery from car catalytic converters. Environment 2017, 9, 133-147.

21. Karagoz, S.; Aydin, N.; Simic, V. End-of-life vehicle management: A comprehensive review. J. Mater. Cycles Waste Manag. 2020, 22, 416-442. [CrossRef]

22. DIRECTIVE 2000/53/EC of the European Parliament and of the Council of 18 September2000 on End-of Life Vehicles. Available online: https:/ / eur-lex.europa.eu/LexUriServ /LexUriServ.do?uri=CONSLEG:2000L0053:20050701:EN:PDF (accessed on 23 September 2020).

23. Eskina, V.; Dalnova, O.; Filatova, D.; Baranovskaya, V.; Karpov, Y. Direct precise determination of Pd, Pt and Rh in spent automobile catalysts solution by high-resolution continuum source graphite furnace atomic absorption spectrometry. Spectrochim. Acta Part B At. Spectrosc. 2020, 165, 105874. [CrossRef]

24. Lee, J.; Raju, B.; Kumar, B.; Kumar, J.; Park, H.; Reddy, B. Solvent extraction separation and recovery of palladium and platinum from chloride leach liquors of spent automobile catalyst. Sep. Purif. Technol. 2010, 73, 213-218. [CrossRef]

25. Zhang, L.; Song, Q.; Liu, Y.; Xu, Z. An integrated capture of copper scrap and electrodeposition process to enrich and prepare pure palladium for recycling of spent catalyst from automobile. Waste Manag. 2020, 108, 172-182. [CrossRef] [PubMed]

26. Puig, A.; Alvarado, J. Evaluation of four sample treatments for determination of platinum in automotive catalytic converters by graphite furnace atomic absorption spectrometry. Spectrochim. Acta Part B At. Spectrosc. 2006, 61, 1050-1053. [CrossRef]

27. Torrejos, R.; Nisola, G.; Min, S.; Han, J.; Lee, S.; Chung, W. Highly selective extraction of palladium from spent automotive catalyst acid leachate using novel alkylated dioxa-dithiacrown ether derivatives. J. Ind. Eng. Chem. 2020, 89, 428-435. [CrossRef]

28. Ilyas, S.; Srivastava, R.; Kim, H.; Cheema, H. Hydrometallurgical recycling of palladium and platinum from exhausted diesel oxidation catalysts. Sep. Purif. Technol. 2020, 248, 117029. [CrossRef]

29. Ferella, F. A review on management and recycling of spent selective catalytic reduction catalysts. J. Clean. Prod. 2020, 246, 118990. [CrossRef]

30. Ciuła, J.; Gaska, K.; Generowicz, A.; Hajduga, G. Energy from Landfill Gas as An Example of Circular Economy. In Proceedings of the First Conference of the International Water Association IWA for Young Scientist in Poland "Water, Wastewater and Energy in Smart Cities", Cracow, Poland, 12-13 September 2017. [CrossRef]

31. Karhu, M.; Bachér, M.; Yli-Rantala, E.; Huttunen Saarivirta, E.; Cordones, P.; Martel Martin, S.; Sanz, M.C. Report on the Economic Assessment of Substitution Trajectories. 2019. Available online: http://scrreen.eu/wp-content/uploads/2019/06/SCRREEN-D5 .3-Report-on-the-economic-assessment-of-substitution-trajectories.pdf (accessed on 28 September 2020).

32. Król, J.; Ocłon, P. Economic analysis of heat and electricity production in combined heat and power plant equipped with steam and water boilers and natural gas engines. Energy Convers. Manag. 2018, 176, 11-29. [CrossRef]

33. Trinh, H.; Lee, J.; Srivastava, R.; Kim, S. Total recycling of all the components from spent auto-catalyst by NaOH roasting-assisted hydrometallurgical route. J. Hazard. Mater. 2019, 379, 120772. [CrossRef]

34. Xun, D.; Hao, H.; Sun, X.; Liu, Z.; Zhao, F. End-of-life recycling rates of platinum group metals in the automotive industry: Insight into regional disparities. J. Clean. Prod. 2020, 266, 121942. [CrossRef]

35. Che, J.; Yu, J.; Kevin, R.S. End-of-life vehicle recycling and international cooperation between Japan, China and Korea: Present and future scenario analysis. J. Environ. Sci. 2011, 23, S162-S166. [CrossRef]

36. LBMA PALLADIUM. Available online: https://www.lme.com/Metals/Precious-metals/Palladium (accessed on 23 September 2020).

37. GUS. Available online: https://bdl.stat.gov.pl/BDL/dane/podgrup/wykres (accessed on 23 September 2020).

38. Moztota, B. Structuring Strategic Design Management: Michael Porter's Value Chain. Des. Manag. Rev. 2010, 9, 2. [CrossRef]

39. Magangement Technology Policy. Available online: https://www.ifm.eng.cam.ac.uk/research/dstools/value-chain-/ (accessed on 23 September 2020).

40. Umicore Investor Presentation. Available online: https://www.umicore.com/storage/group/investor-presentation-october.pdf (accessed on 30 September 2020).

41. Amund, N.L.; Hagelüken, C.H.; Wäger, P. Improving supply security of critical metals: Current developments andresearch in the EU. Sustain. Mater. Technol. 2018, 15, 9-18.

42. Espinoza, L.T.; Schrijvers, D.; Chen, W.; Dewulf, J.; Eggert, R.; Goddin, J.; Habib, K.; Hagelüken, C.; Hurd, A.J.; Kleijn, R.; et al. Greater circularity leads to lower criticality, and other links betweencriticality and the circular economy. Resour. Conserv. Recycl. 2020, 159, 104718. [CrossRef]

43. Bahaloo-Horeh, N.; Mousavi, S.M. Comprehensive characterization and environmental risk assessment of end-of-life automotive catalytic converters to arrange a sustainable roadmap for future recycling practices. J. Hazard. Mater. 2020, 400, 123186. [CrossRef] [PubMed] 